\title{
ANALYSIS OF DIFFERENCES IN THE PROVINCE OF BREASTFEADING BASED ON SOCIODEMOGRAPHIC CHARACTERISTICS IN EAST NUSA TENGGARA PROVINCE, 2017
}

Analisis Perbedaan Lamanya Pemberian ASI Berdasarkan Karakteristik Sosiodemografi di Provinsi Nusa Tenggara Timur Tahun 2017

\author{
Mufidah Anisah $^{1}$, Rafika Diyah Arafah ${ }^{1}$ \\ ${ }^{1}$ Faculty of Public Health, Universitas Airlangga \\ Mufidah.anisah-2017@fkm.unair.ac.id
}

\section{ARTICLE INFO}

Article History:

Received:

December, $19^{\text {th }}, 2020$

Revised:

From January, 28 ${ }^{\text {th }}$, 2021

Accepted:

April, $14^{\text {th }}, 2021$

Published online: September, $30^{\text {th }}, 2021$

\begin{abstract}
Background: The length of time offering breast milk had a relationship with child development. There were several factors that influence whether to offer ASI, one of which wass the sociodemography of the mother.. East Nusa Tenggara Province was one of the provinces with the lowest limit of offering ASI. So it was necessary to analyze the survival with the life table method to see the median life, offering breast milk based on sociodemography. Purpose: The aim of the study was to describe and analyze the time, to offer breast milk to babies based on sociodemography in the province of East Nusa Tenggara. Methods: This study used secondary data from the 2017 IDHS results in the East Nusa Tenggara Region with inclusion criteria, namely women of reproductive age who have or are still breastfeeding in the last five years based on the survey year ( $n=983$ respondents). This research was a descriptive analysis and an analysis of survival using the life table method. Results: The results of this study were the last derivative of offering ASI based on sociodemography with the education variable $(p=0.003)$, there was a significant difference. In the age variable $(p=0.895)$ and the work status variable $(p=0.866)$ there was no significant difference. Conclusion: Based on the results of the study, it can be determined that the sociodemographic criteria were found to be breastfeeding in the last educational variable.
\end{abstract}

Keywords: Life Table Method, Direct Breastfeeding, Sociodemography 
Mufidah, et al. Analysis of Differences in The Province of Breastfeading Based on Sociodemographic

Characteristics in East Nusa Tenggara Province, 2017
JPH RECODE October 2021; 5 (1): 17-25

http://e-journal.unair.ac.id/JPHRECODE

http://dx.doi.org/10.20473/jphrecode.v5i1.23945

\section{INTRODUCTION}

A life table is one of the methods to calculate survival analysis. The life-table method is an analysis based on the time data until the event occurs. The types of event data that can be used to calculate survival analysis using the life table method are the time needed for treatment or recovery, the progression of the occurrence of a healthy person becoming sick. The life-table method concept is a description of an event at a time until it occurs. The life table describes the time with a graph of the life table function and the median time length until the event occurs. The life-table method can be used on large amounts of data (Kuntoro, 2017).

Survival analysis is an analysis that observes an event from the beginning of the event until it occurs. The most commonly used to calculate survival analysis are the life table method, Cox Regression, and Kaplan Meier. The life-table method can be used to analyze large amounts of data and divide time intervals into smaller ones. In the Kaplan Meier method, the analysis is not based on the division of the observation period with a smaller time interval. The Kaplan Meier method is best used for a small data set. Meanwhile, the Cox Regression contains variables that are considered to be related to survival time or controlled variables (IBM Knowledge Center, 2003). The longest distribution of breastfeeding is 48 months or four years of age. Practicing breastfeeding for more than two years is uncommon in developed countries, but it is still common in developing countries such as Indonesia (Lawrence and Lawrence, 2015). Breastfeeding should only be given up to a baby for two years, following WHO recommendations and guidelines (UNICEF, 2018) and Government Regulation Number 33 of 2012 on Exclusive Breastfeeding (Government of Republic of Indonesia, 2012).

The oldest survival analysis method is the life table method. The result of the life table method is a non-parametric life table and a comparison of the duration of endurance and the risk that occurs in the two groups. The lifetable method describes the resistance estimation curve and records the median of the survival time. The midpoint of each group's survival time is the survival time median. Meanwhile, the Actuarial or Cutler-Ederer method is a method by selecting the desired time interval. The selection of time intervals is by pondering the characteristics of an event. The time used can be based on the day, week, month, and year (Hasyim and Prsetyo, 2017).

Survival analysis is a statistical procedure to analyze or estimate the median time of an event in a particular population studied. Survival analysis is also known as time-to-event analysis, which its goal is to estimate the time for an individual or group of individuals to experience a certain event as a response variable. This estimated time is the duration between an initial condition and the occurrence of an event. Survival analysis has been used in various applications, such as the time when treatment started until treatment response appears, as well as the length of the recovery (length of remission), even until the death occurs (Zahid, 2018).

Survival analysis with the life table method can be used to determine the length of time for certain treatments, one of which is to determine the length analysis of breastfeeding for infants. There is a significant relationship between breastfeeding and the children's nutritional status (UNICEF, 2018).

Two studies conducted by (FernándezCañadas Morillo et al., 2017) and (Utami, 2017) stated that several factors lead to breastfeeding failure related to sociodemographic factors: low education level, age, and maternal occupation status. Mothers with poor educational backgrounds tend not to filter various information about breastfeeding. Poor background affects mothers in deciding whether or not to breastfeed their children. Working mothers have limited time to breastfeed compared to non-working mothers. Hence working mothers are likely to give formula milk to their newborns (Mustika, 2017).

A study conducted by (Mawaddah, 2019) reported that babies who were exclusively breastfed affect their growth and nutritional status. Children who were exclusively breastfed had a better nutritional status compared to those who were not. Based on the Basic Health Research result in 2018, East Nusa Tenggara was the province with the highest proportion of short and very short nutritional status among toddlers with indicators of height by age $(\mathrm{TB} / \mathrm{U})$. The percentage of toddlers with short and very short nutritional status in East Nusa Tenggara was $51.7 \%$, which was half of the number of 
Mufidah, et al. Analysis of Differences in The Province of Breastfeading Based on Sociodemographic
JPH RECODE October 2021; 5 (1): 17-25

http://e-journal.unair.ac.id/JPHRECODE

http://dx.doi.org/10.20473/jphrecode.v5i1.23945 toddlers in East Nusa Tenggara (The Ministry of Health, 2019).

Indonesian Demographic and Health Survey (IDHS) of 2017 analysis showed that the median duration of breastfeeding in Indonesia was different based on conditions and characteristics of certain regions. Based on the residence factor, the median duration of breastfeeding in rural areas was 22.4 months, while in urban areas was 20.7 months. Based on the mother's level of education, the higher the mother's education level, the shorter the median duration of any breastfeeding. Meanwhile, based on economic factors, children from households in the lowest wealth quintile are breastfed for 22.6 months (National Population and Family Planning Board, Central Bureau of Statistics, and The Ministry of Health, 2018).

The life-table method was used to analyze the breastfeeding duration by following the first time the mother gave breast milk until the mother stopped breastfeeding. In this research, breastfeeding duration was analyzed due to the proportion of breastfeeding duration in East Nusa Tenggara was still relatively low.

Based on the explanation, the researchers aim to undertake research that used the life table method to describe and analyze the differences in the median duration of breastfeeding based on sociodemographic characteristics in East Nusa Tenggara.

\section{METHOD}

This research used secondary data from the East Nusa Tenggara IDHS 2017. The data used were based on sociodemographic characteristics: age, latest formal education, and occupation. The sampling unit selection was undertaken in two stages: the sampling frame for the census block and the sampling frame for households selection. The sample frame used in this study was the Census Block Master from the 2010 Population Census. Data selection was undertaken using reproductive age women data in East Nusa Tenggara with such inclusion criteria: mothers who were still breastfed or have given breast milk for the last five years $(\mathrm{n}=983)$.

The data used in this research was the IDHS 2017 data. It was collected in September 2017 and the result was published in 2018. The independent variable of this study was the analysis of breastfeeding in infants based on sociodemographic characteristics (age, latest formal education, and mother's occupation). Meanwhile, the dependent variables were the status of the occurrence and the duration of breastfeeding. Age variables were divided into several categories: under 20 years old, 20-35 years old, and above 35 years old. The latest formal education was divided into uneducated, Primary School, Junior High School, Senior High School, or above. The mother's occupation status was divided into unemployed and employed.

Data analysis employed the life table method which showed the output. It displayed the form of a life table display (complete table) which contained time intervals in rows and life table components in columns, then median survival time for each variable category, plot, or graph of the survival function. Those were aimed to determine the risk or opportunity of an event and to determine the result of the difference test using the Wilcoxon test (Gehan).

The research result that has been obtained then being analyzed descriptively. Descriptive analysis is an analysis that describes the sociodemographic characteristics of the respondents, such as age, latest formal education, and occupation. The result of the descriptive analysis will be displayed in the form of frequency and percentage to obtain information related to the condition and proportion of the total research population data. The second analysis was the survival analysis. This analysis was undertaken using the life table method. It analyzed the difference in the median time and describe the duration of breastfeeding in the form of a graphic based on sociodemographic characteristics.

\section{RESULT}

Based on the result of 2017 IDHS, the percentage of children who were not breastfed increased as children's age rises, from $8 \%$ at 0 1 month to $41 \%$ at $18-23$ months. The percentage of breastfeeding among infants aged 0-5 months in East Nusa Tenggara was $18 \%$, which made East Nusa Tenggara ranked in second place with the lowest proportion of breastfeeding. The proportion of breastfeeding among infants aged 0-23 months in East Nusa Tenggara was $57 \%$ which was still below the national average $(58.2 \%)$ (The Ministry of Health, 2019). 
Mufidah, et al. Analysis of Differences in The Province of Breastfeading Based on Sociodemographic

Characteristics in East Nusa Tenggara Province, 2017

\section{Characteristics of the Respondent in East Nusa Tenggara}

Table 1. Frequency Distribution Based on Sociodemographic Characteristics

\begin{tabular}{lccc}
\hline Characteristics & $\mathbf{f}$ & $\%$ & $\begin{array}{c}\text { Time } \\
\text { Median } \\
\text { (Month) }\end{array}$ \\
\hline Age & & & \\
\hline$<20$ years & 266 & 27.1 & 14.91 \\
20-35 years & 708 & 72.0 & 15.65 \\
$>35$ years & 9 & 0.9 & 21.57 \\
\hline Education & & & \\
\hline No education & 56 & 5.7 & 14.24 \\
Primary School & 383 & 39.0 & 16.07 \\
Junior High School & 414 & 42.1 & 15.82 \\
Senior High School & 130 & 13.2 & 12.79 \\
or above & & & \\
\hline Occupation & & & \\
\hline Unemployed & 472 & 48.0 & 15.32 \\
Employed & 511 & 52.0 & 15.41 \\
\hline
\end{tabular}

Source: 2017 IDHS Data of East Nusa

Tenggara

Based on Table 1, the majority of the mothers who breastfed were aged 20-35 years, which were 708 respondents or $72 \%$, meanwhile, the least number of the respondents were among mothers whose age was $>35$ years, which were 9 respondents or $0.9 \%$. There were 266 respondents aged $<20$ years or as much as $27.1 \%$. The total of respondents was 983 respondents.

The latest formal education of the majority of the mothers was Junior High School with 414 respondents or $42.1 \%$, and the fewest education of the mothers were the ones with no education with 56 respondents or $5.7 \%$. The majority of mothers' were employed with 511 respondents or $52 \%$, and the ones who were unemployed were 472 respondents or $48 \%$.

\section{Median Duration of Breastfeeding in East Nusa Tenggara}

The life table method in this study resulted in the median duration of breastfeeding. Considering that this study used big data, the data tend to be not normally distributed and there were extreme. Thus, the median method was a more stable method than the mean and mode method (Ananda, Rusydi, and Fadhli, 2018).

The median duration of breastfeeding among mothers aged $<20$ years, 20-35 years, and >35 years were 14.91 months, 15.62 months, and 21.57 months, respectively. The highest median of breastfeeding was among mothers aged $>35$ years, while the lowest was among mothers aged $<20$ years.

The median of breastfeeding among mothers with no education, mothers who graduated from Primary School, Junior High School, and Senior High School or above were 14.24 months, 16.07 months, 15.82 months, and 12.79 months, respectively. The highest median of breastfeeding was among mothers with Primary School as their latest formal education.

The median of breastfeeding among mothers with no occupation and the ones with an occupation were 15.32 months and 15.41 months, respectively. Hence, the highest median of breastfeeding was among mothers with occupations.

\section{The Graph of Life Table Function in East} Nusa Tenggara Based on Age

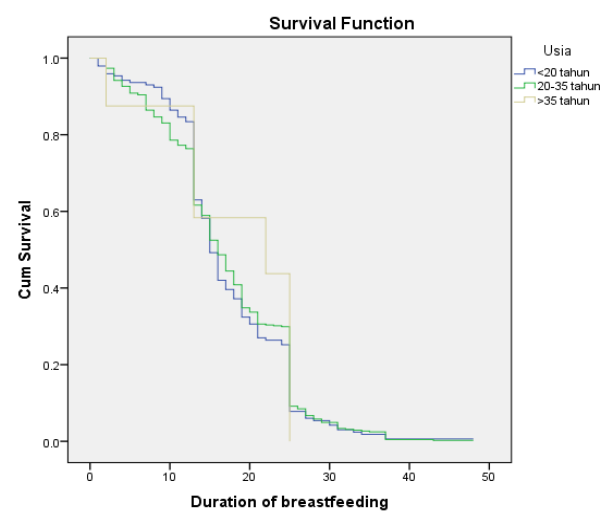

Figure 1. Graph of the Breastfeeding Duration Based on Mother's Age

The graph of the function showed that mothers aged $>35$ years in the first until second months were at the maximum opportunity, and it decreased to 0.9, then declined in the $11^{\text {th }}$ month and $21^{\text {st }}$ month by 0.6 and 0.4 . until the $24^{\text {th }}$ month, all data showed that it was the end time. The groups of mothers aged 20-35 years and $>35$ years had a relatively similar graph. From the beginning of the month until the $12^{\text {th }}$ month, the cumulative score was dominated by the group of mothers aged $<20$ years, and at the $13^{\text {th }}$ month until the $48^{\text {th }}$ month, the cumulative score was dominated by the mothers aged $>35$ years.

The Graph of Life Table Function in East Nusa Tenggara Based on Level of Education 
Mufidah, et al. Analysis of Differences in The Province of Breastfeading Based on Sociodemographic

Characteristics in East Nusa Tenggara Province, 2017

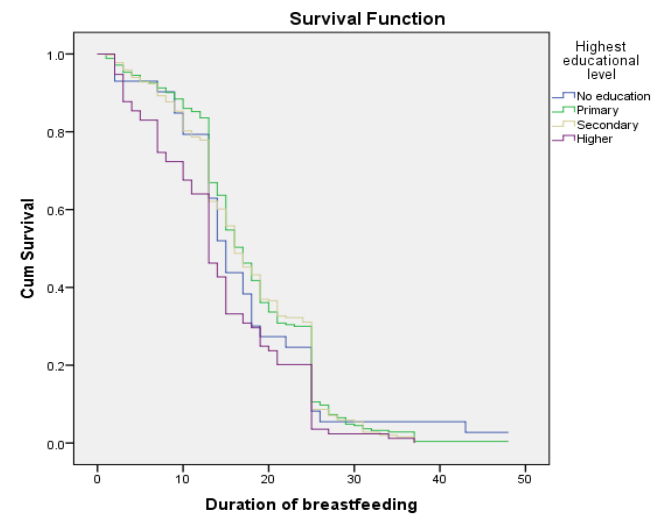

Figure 2. Graph of the Breastfeeding Duration Based on Mother's Latest Formal Education

The graph of the life table function compared the duration of breastfeeding between mothers based on their last formal education, which were no education, Primary School, Junior High School, and Senior High School or above. The graph showed a function of time that likely to alter, in the $8^{\text {th }}$ to $14^{\text {th }}$ month, the opportunity and the duration of breastfeeding were longer among mothers with Primary School as their latest formal education. From the $14^{\text {th }}$ to the $31^{\text {st }}$ month showed a different function of time, the dominance changed between mothers whose latest formal education was Primary School and Junior High School. However, from the $32^{\text {nd }}$ month to the maximum time of the $48^{\text {th }}$ month, the cumulative value of breastfeeding duration among mothers with no education was higher in terms of time and opportunity than the other groups of mothers based on their latest formal education.

The Graph of Life Table Function in East Nusa Tenggara Based on Mother's Occupation

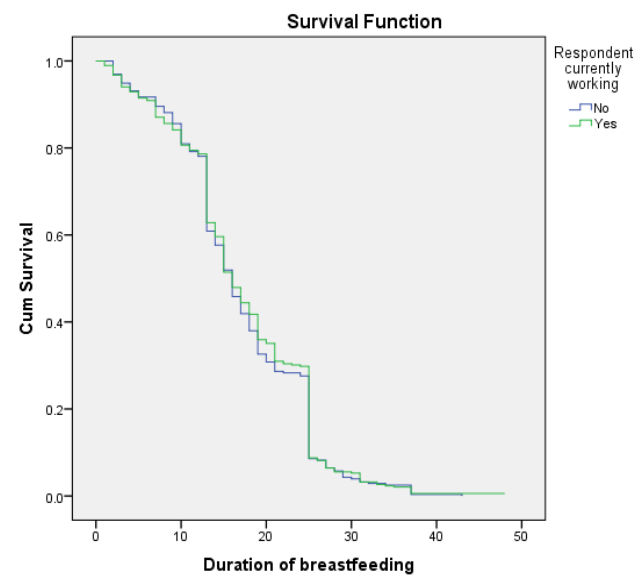

Figure 3. Graph of the Breastfeeding Duration Based on Mother's Occupation
JPH RECODE October 2021; 5 (1): 17-25

The graph of the life table function showed the distribution of time patterns that tend to be the same between categories of mother's occupation. The graph showed that at the beginning of the $10^{\text {th }}$ month the opportunity and the duration of breastfeeding was longer among non-working mothers, and at the $12^{\text {th }}$ month to the maximum time, the $48^{\text {th }}$ month, the cumulative value of breastfeeding duration was higher among mothers with occupation.

Median Duration of Breastfeeding Differences in East Nusa Tenggara

Table 2. Wilcoxon Test of Breastfeeding Duration Based on Sociodemographic Characteristics

\begin{tabular}{llll}
\hline \multicolumn{1}{c}{ Variable } & $\begin{array}{l}\text { Wilcoxon } \\
\left(\begin{array}{c}\text { Gehan }) \\
\text { Statistic }\end{array}\right.\end{array}$ & Df & Sig. \\
\hline Age & 0.223 & 2 & 0.895 \\
\hline Latest Formal Education & 14.016 & 3 & 0.003 \\
\hline Occupation & 0.029 & 1 & 0.866 \\
\hline
\end{tabular}

The statistical test was carried out to determine the difference in the median duration of breastfeeding between mothers aged $<20$ years, 20-35 years, and $>35$ years. The statistical test in this study was using Wilcoxon (Gehan), the result reported that the p-value $=0.895$ with $(\alpha)=0.05 \quad(5 \%)$. Therefore, it showed that there was no difference in the median duration of breastfeeding between these groups of mothers aged $<20$ years, 20-35 years, and $>35$ years.

The statistical test was also carried out to examine the difference in the median duration of breastfeeding between mothers according to their latest formal education, namely no education, Primary School, Junior High School, and Senior High School or above. The result of Wilcoxon (Gehan) test showed the p-value $=0.003$ with $(\alpha)=0.05$ $(5 \%)$. Hence, it indicated that there was a difference in the median duration of breastfeeding between mothers based on their latest formal education.

The statistical test was also carried out to examine the difference in the median duration of breastfeeding between mothers with occupation and without occupation. The result of Wilcoxon (Gehan) test stated that the p-value $=0.866$ with $(\alpha)=0.05(5 \%)$. Thus, it showed that there was no difference in the median duration of breastfeeding between mothers based on their occupation status. 
Mufidah, et al. Analysis of Differences in The Province of Breastfeading Based on Sociodemographic
JPH RECODE October 2021; 5 (1): 17-25

http://e-journal.unair.ac.id/JPHRECODE

http://dx.doi.org/10.20473/jphrecode.v5i1.23945

\section{DISCUSSION}

\section{Median Duration Based on Mother's Age}

The comparison of the median duration of breastfeeding in infants based on the mother's age showed an insignificant result. The result of the Wilcoxon (Gehan) test showed that there was no difference in the median duration of breastfeeding by mothers with different age categories. The comparison of the median duration of breastfeeding between categories showed that the highest median was among mothers aged $>35$ years. While the lowest was among mothers aged $<20$ years. The median difference between these two categories was 6.66 months.

Another study reported that there was no difference in the proportion of breastfeeding with the mother's age (Fakhidah and Palupi, 2018). The result was in line with a study conducted in Minggir Public Health Center Sleman Regency which showed that there was no relationship between mother's age and breastfeeding practice (Untari, 2017).

Maternal age is related to the mother's physical and mental state. It is considered to be too young if a mother gets her pregnancy at the age of under 20 years. At the age of 20-35 years, mothers are suggested to adjust the distance between pregnancies, four years was the ideal length. Furthermore, at the age of $>35$ years, it is better to be less likely to get pregnant as woman's reproductive health starts to decline (Triseptinora, 2019).

The best age to produce breast milk is the age of 20-35 years. However, the age of 20-25 years is relatively a young age and psychologically immature, causing the mother to respond with fear, nervousness, and confusion when the baby cries. The mother's unease is due to a lack of psychological readiness. Thus, it affects breast milk production. Meanwhile, the reproductive function among mothers whose age is above 35 years has decreased. However, these groups of mothers had a good psychological readiness as they already had breastfeeding experiences obtained from themselves, family, or friends (Rahmawati and Prayogi, 2017).

Mothers who breastfed for a shorter time usually due to the unreadiness psychologically, especially the mothers whose age is $<20$ years. Meanwhile, mothers whose age is $>35$ years are likely to breastfeed for a longer time as they have breastfeeding experience from the previous children and they have a better emotional condition. However, the hormone secretion decreases as the mothers' age rises, which hinders the mothers to breastfeed their children (Maulida, Afifah, and Pitta Sari, 2015).

\section{Median Duration Based on Mother's Latest Formal Education}

The statistic result on the latest formal education variable showed that there was a difference in the median duration of breastfeeding by mothers based on this category. The result of the median duration of breastfeeding based on mother's education, the highest median was among mothers with Primary School as the latest formal education, which was 16.07 months. While the lowest median was among mothers who graduated from Senior High School or above, which was 12.79 months. The median difference between the two categories was 3.28 months.

This result had a similar result with a study by (Simanungkalit, 2018) which reported that there was no relationship between the duration of breastfeeding and mother's education. It was due to the decision to breastfeed was not only influenced by the level of education. Mothers with a high level of education are not always in line with the knowledge about their knowledge about the importance of breastfeeding. Thus, a person's level of education is not a factor to determine the practice of breastfeeding.

This finding was in accordance with another study that explained there was a relationship between mother's education and the duration of breastfeeding. Mothers with lower education are likely to have more time to breastfeed their children as mothers with higher education levels have the greater possibility to be at work or even be in a higher position. This condition causes mothers to have a limited time to breastfeed their children or to continue to breastfeed but in a shorter time (Sriningsih, 2011).

The result was consistent with other study stated that there was a relationship between mother's education level and breastfeeding practice. Mother's education level is one of social aspect that affect their intention. Mothers with higher education have more rational thoughts than the ones with low education. It is also known that mothers with higher education are easier to receive information (Lindawati, 2019). 
In line with other research which stated that mother's education was correlated with the practice of breastfeeding. Mother's education is an important contributor to the practice of breastfeeding among infants as mothers with higher education levels tend to seek more information and are easier to receive new information that applies in everyday life (Sihombing, 2018).

Another study showed that mother's latest formal education was not correlated with the exclusive breastfeeding practice. However, it was correlated with the mother's perception of breastfeeding practice (Kusumastuti, 2014).

\section{Median Duration Based on Mother's Occupation}

Based on statistical analysis, it was shown that there was no significant difference between the category of mother's occupation and the duration of breastfeeding. The median comparison between categories showed that the median duration of breastfeeding was higher among working mothers, which was 15.41 months. While the median of breastfeeding among non-working mothers was lower, which was 15.32 months. The median difference between both categories was very small, it was 0.09 months or about 2-3 days.

Another study supported the result of this research which reported that the mother's occupation practice was not correlated with the breastfeeding practice in Minggir Public Health Center Sleman Regency (Untari, 2017). In line with a study conducted in Semarang Utara District, stated that the mother's occupation had no relationship with the practice of breastfeeding among infants (Swandayani et al., 2018).

A study also reported that mother's occupation had no relationship with the success of breastfeeding practice, however a mother's working hours and support from the mother's workplace had a significant relationship with breastfeeding practice (Rosyadi, 2016).

Another study stated that there was no relationship between mother's occupation and the practice of breastfeeding. The study obtained that many non-working mothers did not practice breastfeeding as there was only a small amount of breast milk supply thus the mothers gave formula milk to their children (Pipitcahyani, 2018).
This finding was in agreement with another study which explained that breastfeeding practice was not determined by mother's occupation. This was because both working and non-working mothers received the same information regarding breastfeeding practice. Thus, both groups of mothers had the same awareness to give breast milk to their children (Fakhidah and Palupi, 2018).

The same result showed by a study conducted by (Mastuti, Sariati, and Fathma, 2017) showed that mother's occupation was not a determinant factor of breastfeeding, because indeed working and non-working mothers have could still give breast milk. Mothers who do not work tend to have a longer time at home to give breast milk and mothers who work can give breast milk by pumping

\section{CONCLUSION}

Based on the result, it can be concluded that the majority of the respondents were aged 20-35 years, had Junior High School as their latest formal education, and working mothers. The highest median of breastfeeding was among mothers aged >35 years or above, mothers with Primary School as their latest formal education, and among working mothers.

There was a difference in the duration of breastfeeding in the variable of the mother's latest formal education. There was no difference in the duration of breastfeeding in the variables of mother's age and occupational status.

\section{SUGGESTION}

\section{Suggestions for the Community}

Mothers with sociodemographic characteristics that have a low median duration of breastfeeding should anticipate and seek alternative solutions immediately, hence under these conditions, the mother can be able to breastfeed until the baby reaches two years of age.

\section{Suggestions for the East Nusa Tenggara Government}

The result of the study can contribute to evaluation and recommendation to improve health promotion and to educate the community regarding the importance and benefits of breastfeeding to improve nutritional status in East Nusa Tenggara. 
Mufidah, et al. Analysis of Differences in The Province of Breastfeading Based on Sociodemographic

\section{REFERENCES}

Ananda, Rusydi, Fadhli, M. (2018) Statistik Pendidikan. Teori dan Praktik Dalam Pendidikan. Edited by S. Saleh. CV.Widya Puspita.

BKKBN, BPS and Kemenkes RI (2018) Indonesian Health Demographic Survey, Usaid. Jakarta: Kementrian Kesehatan.

Fakhidah, L. N. and Palupi, F. H. (2018) 'ANALISIS FAKTOR YANG MEMPENGARUHI PEMBERIAN ASI EKSKLUSIF', Jurnal Kebidanan. doi: 10.35872/jurkeb.v10i02.291.

Fernández-Cañadas Morillo, A. et al. (2017) 'A Comparison of Factors Associated with Cessation of Exclusive Breastfeeding at 3 and 6 Months', Breastfeeding Medicine, 12(7), pp. 430-435. doi: 10.1089/bfm.2017.0045.

Hasyim, M. and Prsetyo, D. . (2017) Analisis Survival Menggunakan Program IBM SPSS 2003. Bandung: Ristekdikti.

IBM Knowledge Center (2003) Related Procedure in Life Table. International Business Machine Corporation.

Kemenkes RI (2019) 'Laporan Nasional Hasil Riset Kesehatan Dasar (Riskesdas) Indonesia tahun 2018', Riset Kesehatan Dasar 2018. Jakarta: Kementrian Kesehatan Republik Indonesia, pp. 68-72.

Kuntoro, H. (2017) Analisis Kelangsungan Hidup. Surabaya: Airlangga University Press.

Kusumastuti, D. A. (2014) 'Korelasi Faktor Sosio Demografi Dengan Pelaksanaan Pemberian Asi Eksklusif Di Kabupaten Kudus', STIKES Muhammadiyah Kudus, 5, pp. 60-69.

Lawrence, R. A. and Lawrence, R. M. (2015) Breastfeeding - A guide for medical profession, Elsevier. Florida: Elsevier Inc. doi: 10.1017/CBO9781107415324.004.

Lindawati, R. (2019) 'Hubungan

Pengetahuan, Pendidikan dan Dukungan Keluarga dengan Pemberian ASI Eksklusif', Faletehan Health Journal, 6(1), pp. 30-36. doi: 10.33746/fhj.v6i1.25.

Mastuti, N. L. P. H., Sariati, Y. and Fathma, P. (2017) 'Pengaruh Durasi
JPH RECODE October 2021 ; 5 (1): 17-25 http://e-journal.unair.ac.id/JPHRECODE http://dx.doi.org/10.20473/iphrecode.v5i1.23945

Dan Tahapan Pelaksanaan Inisiasi Menyusu Dini (IMD) Terhadap Keberhasilan Pemberian Asi Eksklusif Dalam 1 Bulan Pertama', Majalah kesehatan FKUB, 4(3), pp. 149-157. doi:

10.21776/ub.majalahkesehatan.2017.0 04.03.6.

Maulida, H., Afifah, E. and Pitta Sari, D.

(2015) 'Tingkat Ekonomi dan Motivasi Ibu dalam Pemberian ASI Eksklusif pada Bayi Usia 0-6 Bulan di Bidan Praktek Swasta (BPS) Ummi Latifah Argomulyo, Sedayu Yogyakarta', Jurnal Ners dan Kebidanan Indonesia, 3(2), p. 116. doi: 10.21927/jnki.2015.3(2).116-122.

Mawaddah, S. (2019) 'Hubungan

Pemberian Asi Eksklusif Dengan Kejadian Stunting Pada Balita Usia 24-60 Bulan', Jurnal Berkala Kesehatan, 5, pp. 60-66. doi: 10.34035/jk.v12i1.545.

Mustika, I. (2017) 'Determinan Pemberian ASI Eksklusif pada Ibu Menyusui Tinjauan Sistematis Peneitian Tahun 2011-2016', Journal of Health Science and Prevention, 1.

Pipitcahyani, T. I. (2018) 'Pendidikan dan Pekerjaan Ibu terhadap Pemberian ASI', Jurnal Informasi Kesehatan Indonesia (JIKI), 3(2), pp. 158-162. doi:

10.31290/jiki.v(3)i(2)y(2017).page: 15 8-162.

Rahmawati, A. and Prayogi, B. (2017)

'Analisis Faktor yang Mempengaruhi Produksi Air Susu Ibu (ASI) pada ibu Menyusui yang Bekerja', Jurnal ners dan Kebidanan, (4(2)), pp. 134-140.

Rosyadi, D. . (2016) Hubungan antara

Pengetahuan Ibu Bekerja, Jam Kerja Ibu, dan Dukungan Tempat Kerja dengan Keberhasilan Pemberian ASI Eksklusif di Wilayah Kerja Puskesmas Banyudono $1 . \quad$ Universitas Muhammadiyah Surakarta.

Sihombing, S. (2018) 'Hubungan

Pekerjaan Dan Pendidikan Ibu Dengan Pemberian Asi Ekslusif', Midwifery Journal, 5(01), pp. 40-45.

Simanungkalit, H. M. (2018) 'Status

Pekerjaan Dan Pengetahuan Ibu Menyusui Terhadap Pemberian ASI Eksklusif', Jurnal Info Kesehatan, 
16(2), pp. 236-244. doi: 10.31965/infokes.vol16.iss2.222.

Sriningsih (2011) 'Faktor Demografi,

Pengetahuan Ibu tentang Air Susu Ibu dan Pemberian ASI Eksklusif.', Jurnal Penelitian dan Pengembangan Kesejahteraan Sosial, pp. 100-106.

Swandayani, P. . et al. (2018) 'Payudara dan Laktasi', Journal of Nutrition College.

Triseptinora, R. (2019) 'Hubungan Umur

Pengetahuan Dan Pekerjaan Ibu Dengan Pemberian Asi Eksklusif Di Puskesmas Kenali Besar Kota Jambi Tahun 2018', Scientia Journal, 8(1), pp. 294-304. doi: 10.35141/scj.v8i1.497.

UNICEF (2018) 'Breastfeeding: A mother's gift, for every child UNICEF DATA', Unicef, pp. 1-13.

Untari, J. (2017) 'Hubungan antara

Karakteristik Ibu dengan Pemberian ASI Eksklusif di Wilayah Kerja Puskesmas Minggir Kabupaten Sleman', Jurnal Formil (Forum Ilmiah) KesMas Respati, 2(April), pp. 17-23. Available at: http://formilkesmas.respati.ac.id/index. php/formil/article/view/58/31.

Utami, M. (2017) Hubungan Pelaksanaan

Inisiasi Menyusui Dini(IMD) dan Faktor Sosiodemografi Ibu dengan Keberhasilan Pemberian ASI Eksklusif pada Bayi Usia 6-11 Bulan di Wilayah Kerja Puskesmas Baki Sukoharjo. Fakultas Ilmu Kesehatan Universitas Muhammadiyah Surakarta.

Zahid, T. (2018) 'Survival Analysis-Part A An Introduction to the Concepts of Survival Analysis and Its implementation in Lifelines Package for Python', Towards Data Science. 